\title{
Chief Isaac Oluwole Delano: A Legend and His Legacy
}

Toyin Falola

University of Texas at Austin

toyinfalola@austin.utexas.edu

No honor befits a person who enjoys life without helping his country. What glory is entitled to a lazy person that the courageous man does not have? The head of a lazy person is not comparable to the nail of the strong; shame follows the pride of the lazy. ${ }^{2}$

Chief Isaac Delano discovered his intellectual mission during the colonial moment. The nature of the colonial state influenced his writings. The body of his work operated in a context of colonial-modernist state.

The colonial power, in its imperialist/messianic philosophy and the quest to inscribe European ethos on other cultures, the colonized people of Nigeria, like others elsewhere, were told that the root to modernity was the European way of life. Though it claimed to be liberal as it evolved from an already civilized society, "magnanimous" enough to spread the gospel truth of this civility and civilization to other societies still living far below their human potentials in their various crude and barbaric enclaves, it was not liberal enough to the extent of accommodating all indigenous cultural elements of the colonized people. Delano had to respond to the limitation of the colonial modernist project.

Thus, for one to be qualified as being civilized—or call it "modern" if you like-is to be successful in the indoctrinated inevitability of combating every feature of one's culture, values, and traditions to win the trophy of modernity.

1 Originally published as Chapter 14 in Toyin Falola. Cultural Modernity in a Colonized World: The Writings of Chief Isaac Oluwole Delanọ. Austin: Pan-African University Press, 2020.

2 D. O. Fagunwa, Ògbójú Ode Nínú Igbó Irúnmalẹ, quoted in Toyin Falola, "Yoruba Writers and the Construction of Heroes," History in Africa, Vol. 24, 1997, 162. 
Delano sought to reject the assumption of the possibility of Yoruba cultural degradation.

During the early stages of this colonial modernist evolution, the indigenous fellow must be lettered, dressed like the District Officers, and had foreign names. He could also add a mustache to complete the look, speaking the Queen's language as much as those in England, eating the same food as the colonial governor even when such disturbed his belly, and most importantly, believing in the same religious and family principles as with many Europeans. Such an assimilated fellow was a champion of civilization who had fought and won the "Just War." Hence, the death of indigenous cultures became synonymous with civilization in this age. Yet, this triumph over the "darkness" of African traditions could not equate this champion with his European counterparts. Delano noticed the fault-lines in the adoption of a colonial assimilationist strategy.

Delano was right. The colonized remained a second-class citizen of the world, including in his own state. Time and conscious education, which together gave room for reflection on long-held ideas and principles, soon presented to this fellow and others in this category, the latent picture of the European mission of taxonomic civilization. As diversely discussed in various parts of the preceding chapters, it was within this condition that African literature and intellectual productions were made, among other things, as a medium of protest against the excesses of the European cultural dominance and campaign towards cultural revival. ${ }^{3}$ Indeed, "African heritage had never deemed more pertinent than it did at the turn of the second millennium." Delano, like other consciously educated individuals during this period, documented their thoughts on the transitions of the period, as presented in this book.

In the final analysis of studying these paradigm thoughts by Delano and his contemporaries, how do they impact on the contemporary development of our society? Put differently-it has been more than half a century now since the likes of Delano had engaged the topic of cultural rejuvenation for the manifestation of genuine progress in the society, owing to their realization of the simple truth that unconscious progression of the society into what is called "modern" is the handwriting of retrogression-what are the gains and limitations of these calls?

3 This metamorphosed into what Mazrui referred to as trans-African Pan-Africanism, Ali A. Mazrui, "Africa Between Nationalism and Nationhood a Political Survey," Journal of Black Studies, Sage Publications, Vol. 13, No.1, 1982.

4 Derek R. Peterson, Kodzo Gavua and Ciraj Rassool, eds, The Politics of Heritage in Africa: Economies, Histories, and Infrastructures. (London and New York, NY: International African Institute and Cambridge University Press, 2015), xv. 
In addressing this pertinent question, this concluding chapter aims to complement all that has been said in this work-i.e., culture, modernity, and development from the vantage point of Delano's ideas-with the view of bringing the discussion to the realm of emphasizing the central messages embedded in Delano's works and activities for the current Nigerian situation. Moreover, what is the essence of discussing culture without attention being paid to its material implications? ${ }^{5}$

This is an instructive question that has been addressed in various parts of this book. Tellingly, the assimilated "Champion" briefly described above had only one thing in mind when he fought the "demon" of tradition: the social mobility value of the Western culture that was rightly expected to bring him recognition and material gains in the emergent society. Although with the efforts of the likes of Delano, there has been a new turn in the pursuit of this modernity and validation of civility and civilization, this still remains far below what has been referred to as the petit modernization of the SouthEast Asian states. In the area of clothing, the argument seems to have been won in the promotion of African dresses; coming to the Nigerian church, some church doctrines have become relatively less stringently opposed to Africanity.

But these assimilationist wins are far less the case in the areas of education and the economy of the state; the two major "districts" that manifest the material gains of a culture which contemporary scholars now refer to as the interlocking effect of the town and the gown. ${ }^{6}$ As earlier established in the prologue to the study, time is essential to reconstructing truths from fallacious indoctrination, but constant conscious education is deeply germane to sustaining the conviction. This explains why education has been identified as the nucleus of civilizations. A weak educational sector pontificates at a weaker state. ${ }^{7}$ In spite of the perceived and apparent limitations of the Ife Six-Year Primary Project, which Delano was deeply involved with, it is quite unfortunate

5 For more on culture and development see, among others, Ngugi Wa Thiong'o, Moving to the Centre: The Struggle for Cultural Freedom (London: James Currey, 1993); Toyin Falola, The Toyin Falola Reader on African Culture, Nationalism, Development and Epistemology. (Austin, TX: Pan-African University Press, 2018).

6 This has been at the center of contemporary scholarly debate aiming at reformation of the educational sector in Nigeria. See Toyin Falola, "Technology, Culture and Society," First Distinguished Annual Lecture, First Technical University, (Ibadan, July 4, 2019); Toyin Falola, The Humanities in Africa: Knowledge Production, Universities, and the Transformation of Society, (Austin, TX: Pan-African University Press, 2016).

7 Cf. Damilola S. Osunlakin, "Educational System and the Challenges of Restructuring Nigeria for Sustainable Development," in Abdullahi M. Ashafa, et al., Humanities and The Challenge of Development: Interrogating Nigeria's Nation Building Project Since 1960, (Kaduna: Department of History, Kaduna State University, 2019): 33-48. 
that the noble parts of the project could not be brought to fruition as its baby was eventually thrown out with the bathing water.

The contemporary school syllabus is still largely colonial-oriented; just as the country has willfully pressed-on to maintain the colonial structured economy. These two are inseparable-the colonial government knew this. So, the education during its days was structured towards producing a dependent colonial economy. This should not be a surprise because, be that as it may, the "natives" were supposed to look up to the West for their survival, like the God-chosen-people-the Israelites-looked up to Yahweh for instructions and supplies from heaven in the biblical account of Exodus. Only that in this case, manna was not raining down for the colonized people of Nigeria; it was bought with their hard-earned money meant to be re-invested in their economy. What I am saying in essence is that since the European mission of colonization came with the mission of civilization, all that the people and their society could become was dependent on the pattern that was favorable to the colonial economy. So, in terms of education and economy, they received resources to the degree of the dictates of colonial power. This has remained the same even when we profess independence: The educational system was meant to produce graduates for white collar jobs to the detriment of the blue collars. Looking back, the system produced lawyers, doctors, accountants, surveyors, teachers, administrators, architects, pharmacists, and many more. What nation has ever developed with attention solely focused on this category of population? But, as it were in the Nigeria of the colonial period, they remained the quintessential measure of success; the most revered, positioned for government appointments.

It is no brainer that government patronage remains the most viable path to prosperity in the country; an indication that the country is skewed towards consumption, more than it does towards production. If anyone is in doubt of the influence of these fields of study on the psychology of an average Nigerian, a random visit to any of our primary and secondary schools would suffice. After asking the pupils and students about their career goals-if they know what you mean, and this claim is confirmed-go to their parents and ask them about their thoughts for the future of their children. The conclusion you're most likely to arrive at is that over $95 \%$ of the population wants to or wants their children to belong to any of these elite job categories. They don't even want to become school teachers! The list of occupations is in no way exhaustive, but when they tell you one outside of it, it's very likely to be part of the "and many more." This is not to condemn the relevance of these occupations. The point is, civilizations are not built solely on those who earn salaries or lawyers who get paid for their "talking" services. Rather, civilizations are built on the complimentary efforts of these people and those whose markets/ 
products they patronize. Succinctly put, the economy would go nowhere when the money earned by these people is almost exclusively spent on foreign goods and services. The implication of this would be a reflection of the popular Nigerian parlance, "monkey dey work, baboon dey chop."

In that case, whatever the lawyers, the teachers, the doctors, and others earn in Nigeria would continue to be used to partly develop other countries insofar as our industries are dead. Thus, what has the occupational priority choice of the people got to do with this? During the days of the "unsolicited civilization mission," 8 it was difficult for the local industries to thrive because of three major things: the unrestrained influx of foreign goods; the high cost of producing similar goods here because of the disparities in technological advancements of the colony and the imperial Western countries, with concomitant effects on the prices of similar goods; and the emergence of new jobs that promised to be more lucrative than grinding to resolve the disparities. Even though the missionaries established vocational institutions and made efforts to promote agriculture with the view of aiding indigenous productions, ${ }^{9}$ the graduates of these institutions could not meet up with their foreign competitors. At any rate, using a European made pot, for instance, was a matter of class. You had to be more European-inclined for your social status to be validated in the colonial state. The most effective weapon in painting everything and anything African as inferior to that of Europe was Christianity, and many of the "civilized" people at the time professed Christianity. For the Muslims, the dominance of Christianity and Western culture left them in confusion between the East and the West on the one hand, and the foreign and the traditional on the other hand. As the Balógun of İgbèin noted in L'Ớ jọ Ojọ Un, the state was between the Christians and the rest. In any case, no one wanted to work from morning till night with little or nothing to show for it, while other

8 Although some have correctly claimed otherwise, citing the instances of the exslaves who purposely demanded that the European missionaries and governments should help liberate their people from the mentality that allowed them enslave their own people and commit all sorts of barbaric acts, with the hope of establishing European government model in these societies, the truth still remains that with or without these few individuals, the civilization mission would have taken place any way because without this, there would be no effective colonization. In any case, what these ex-slaves called barbaric act of their people, upon which the Europeans were to liberate them, was not exclusive to their people. Even though the Europeans did not use their own people on the plantation farms, they used Africans which boosted the slave trade, with justification of the racial hierarchical structure of the world. And for the barbaric acts like human sacrifice, it is a known fact that no culture in the world can be insulated from this practice.

9 Cf. J. F. Ade Ajayi, "The Development of Secondary Grammar School Education In Nigeria," Journal of the Historical Society of Nigeria, Vol. 2, No. 4, 1963; J. F. Ade Ajayi (ed.), General History of Africa: VI Africa in the Nineteenth Century until the 1880s, UNESCO Publishing, Paris, 1998, 18. 
earning salaries were living over and above them. They were not appreciated, the same way their grafts and products were relegated to the background and now a new class of people had emerged to enjoy all that the time had to offer.

Even when prices were right, the need to reinforce one's status in the colonial state made foreign goods the choice of call, further leaving them in despair. Literarily, the death of local industries spelt the demise of the culture of production. The schools were no longer in shape to produce artisans and other skilled workers, but routine administrators. The consequence of this did not take long to be seen. In an article published by the Echo in 1940, Delano joined his voice to the many evangelistic voices admonishing and mobilizing people back to the kingdom of farming. ${ }^{10}$ In the said article, which remains instructive till date, Delano was convinced that many of the youths migrating to the cities were not qualified to secure jobs, were the jobs to be available: "I believe we have got to go back to the land not only because we ought to, but because we must. The land provides our greatest industry-the only one that never gets outworn."11 Yes! The farming population was already so far depleted that foods that used to be in surplus had become scarce at this time. Progressively, the situation became worse, ${ }^{12}$ and in his 1974 convocation lecture and acceptance speech of his Honorary Doctorate degree award at the then University of Ife (now Obafemi Awolowo University), Delano returned to this issue. This time, he was not admonishing youths to go back into farming, but the question he raised and the panacea he posed are two instructive thoughts that we need to think about today. Although this had been noted in the prologue section of this study, it bears reiterating here for its importance:

Why can't the farmer after a day's toil sit quietly in his home, read a little history, or romance or a play or play on the piano and his kiddies and wife moving about the house enjoying life like the family of a lawyer? ${ }^{13}$

He then went on to suggest three things:

10 Isaac O. Delano, "Back to the Land," The Western Echo, Ibadan, Vol. 1 No. 4, 9th February, 1940.

11 Ibid.

12 Not only in Nigeria, but the whole of Africa. See, for instance, Wale Adebanwi, ed., The Political Economy of Everyday Life in Africa: Beyond the Margins (London: James Currey, 2017).

13 Chief Isaac O. Delano, "Address to the Special Convocation of the University of Ife for Conferment of Honorary Doctorate Degree on him and Dr. T. O. Elias," October 19, 1974. 
(1) make village life very attractive; (2) raise farmers' earnings by substantial government subsidy; (3) accept farmers into our society as honourable men. ${ }^{14}$

It was this condition that he also gave in the 1940 article for him to resign his well-paid job to go back to the farm. Indeed, this goes into how we can revive other industries in the country. How do we make textile, leather, furniture, technological and mechanical productions attractive? The United States of America, like other developed countries-particularly in the West-is filled with Nigerian scientists exploring their talents. How then do we make Nigeria home for them? Even though the children or parents one meets to ask of their career goals or future for their children were to dream outside the painstakingly designed occupations for the economy mentioned above, the informed ones among them would tell you they plan to fly (them) abroad to achieve such a dream. Why not? There are situations where the government invests in scholarship to train some Nigerian youths in Marine Engineering abroad, but never created ground for such youths upon graduation to engage their skills back in Nigeria. Many ended up disappointed and resulted into petty trading or whatever they could engage in to survive, while others who saw ahead never came back from the trip, as they ran to other countries to achieve their dreams in that sector.

It was this kind of scenario that the likes of Fagunwa and Delano envisaged that brought about the Ife Six-Year Primary Project where, among other things, the school curriculum would be tilted towards promoting and preparing students from primary education for blue collar jobs in the western region of the country. As addressed in the documents, one of the challenges of this scheme is the use of Yoruba as the language of instruction in schools in this region, which appeared to be unrealistic because of the cultural complexity of the Nigerian state. The fear was (and still is): how well would these students be prepared for secondary education vis-a-vis their counterparts in other parts of the country? Meanwhile, the adoption of Yoruba in teaching the students, including in science subjects, was premised on UNESCO's findings on the advantage of using indigenous languages to teach students early in life. ${ }^{15}$ Interestingly, countries like China have since adopted this, and its results are conspicuous. Nonetheless, Nigeria is not close to being as homogeneous as China is, so the odds of adopting one native language as a means

14 Ibid.

15 This has been consistently featured in the publications of the organization. See for instance, Jessica Ball, Enhancing Learning of Children from Diverse Language Backgrounds: Mother Tongue-Based Bilingual or Multilingual Education in The Early Years, (Paris: United Nations Educational Scientific and Cultural Organization, 2011). 
of educational communication is not very promising. Even with the success of the call for restructuring, this would be difficult to achieve.

Aside from this, the curriculum and the pedagogy of teaching as designed by this project is something worth going back to. Even though English remains the language of instruction in schools, one central gains of this scheme is in building the cultural, civic, and future consciousness of students from a tender age. As noted in the private papers on this project, schools should maintain quality relationships with artisans outside the school. This way, arrangements could be made for them to have scheduled periods to teach students in various vocations, which would form part of their continuous assessments and grading at the end of each term. Furthermore, they could have access to the workshops of these artisans for some practical assessments. But who would want to leave the school to go freely into an occupation whose practitioners are regarded as lower citizens? With this in mind, and to make this work by way of encouraging the vibrant youths to consider taking careers in this sector, the government must make this attractive by supporting the industry. It needs no telling that governments all over the world play the most important role in the success of both small- and large-scale industries. But when government is mentioned in this kind of thing in this very part of the world, it sounds like a cliché, as in pushing the discussion to an abstract entity that does not exist.

This is where the responsibility of the non-state actors lies. As expressly noted in his books, particularly in African Looks at Marriage and One Church for Nigeria, Delano committed so much faith in the Nigerian Church that he believed it is the nucleus of the society and the architect of change. In these books, Delano informed us that the Church not only has the responsibility to save the country from the impending doom rooted in inequality, prejudice, hate, cultural arrogance, and others, but has to reform itself based on the principle of love, endurance, faith, equality, humility, hope and unity, to be fit to take on this task. This, he premised on two facts: 1) You don't give what you don't have; and 2) If the Nigerian church could successfully ensure these qualities among its teeming members, the society would have less to worry about. Hence, not only would they be carriers of these virtues to reform the state, they, occupying a significant proportion of the population, would be the measure of the reform. It suffices to quickly mention that although his focus was on the church, the responsibility carved for the church as the moral cult of the society also syncs with the Nigerian mosques and Islamic leaders, as the two leading religious bodies in the country. One could only imagine the impact that could be made by these two bodies in upholding the morals of unity, love, service, patriotism and hope among its members, through which they could press for change. 
Delano reminded the Church, which goes for other religious bodies, that as part of the society, whatever affects the society would definitely tell on them. The massive unemployment; death of local industries; deficient school curriculum consistently breeding ignorant graduates; corruption draining the needed resources for development and implementation of adequate policies; increasing inequality; prejudice, nepotism and other forms of favoritism, among others, affects the congregation of these bodies. Interestingly, a majority of those perpetrating the acts leading to the bleeding of the society are either in the church or in the mosque. They are given the front seat and are the most dignified. The religious leaders know this, but will never call them out; in lieu, they sing their praises and give them podium to insult the intelligence of the people. The aloofness and, sometimes, collaboration of the religious leaders, together with the consciously schemed ignorance of the youths through the educational system, make possible the perpetual capture of the society by these elites. In the very least of its intervention, these bodies should stop promoting hate and prejudices. Everyone should be made to choose, freely, which religion that best suits his/her person, and the part of the country one comes from should not be a ground for religious leaders to classify such a person. This low-hanging fruit, if plunged, would dismantle the myth of ethno-religious appeal for election/appointment purposes. To be sure, these two will continue to dominate our politics until these religious leaders take concrete steps. Further into this is that, at the present state of the country, a sincere synergy needs to be built among the religious bodies and other secular ones.

To revive Nigeria and position it on the right path of progress which would see to considerable revolution in its educational and industrial sectors, as well as the bureaucratic structures that gave rise to decadence, attention must be paid to the political culture of the state. With a strong pressure group consisting of the religious bodies, traditional rulers, civil society organizations and professional bodies, these could be achieved in no distant time. Significantly, this led Delano to join the Action Group from the onset. Although not a pressure group, the lofty ideas of the party were propelling. Going through the agenda of the Ife Six-Year Project and the Action Group documents, both of which Delano was a prominent member in, the conformity of both to the revival of the society was palpable. In both cases, one could readily see the need for the repositioning of the local industries and the reorganization of the educational sector. But, as it is with every good policy in the country, none of the ideas rose to sunrise. The free education policy of the Action Group gave room for many to be educated, but this did not amount to change in their political culture. The same folks that enjoyed this basic provision stifled the idea, and the rest of the ideas became demagoguery and election gimmicks. 
Since it is no longer an argument that the Nigerian state has been captured by political cabals for their own self-interest of wealth seeking, and creating tremendous inequality to keep recycling themselves in power, it behooves on the citizens to struggle and step-in to correct the wrongs. No one should be under the illusion that change would come easy since the society has become everyone for himself; God for all. ${ }^{16}$ Nonetheless, the hope for the revival of the political space still resides in the people.

As seen from the insights drawn from Delano's works, there is nothing new in the nature of the decay that we now witness, only that it is getting worse and our yesterday seems to always be better than today. ${ }^{17}$ If Delano could use his writings to negotiate the space with the colonial order, if Delano could use his scholarship to create intellectual progress for the postcolonial state, you and I can do the same to use our creativity, intellect, and imaginations to produce writings of an enduring nature.

Do please join me in this Delanoistic mission!

16 Adegbola mirrored this succinctly as he examined corruption from the sociocultural paradigm that sustains its ballooning manifestation in spite of the several expositions on it for some time now. This is partly due to the surreptitiousness of activities associated with it, because of its obvious links with many traditional cultural forms, and the tendency by academic writers not to wish to ascribe blame to them. Most prominently perhaps, corruption defies easy treatment because of the complexity of the socioeconomic relationships directly responsible for its presence and reach. Daniel Egiegba Agbiboa, "Serving the Few, Starving the Many: How Corruption Underdevelops Nigeria and How There Is an Alternative Perspective to Corruption Cleanups," Africa Today, Indiana University Press, Vol. 58, No. 4, 2012, 111.

17 Such forward-looking writings that appear to illuminate the intricacies of the present we live in and warn us about the future we tread from the past presented in history and fiction, was deployed by Delano. As we have noted earlier, also in this same category are the works of D. O. Fagunwa, Akinwunmi Isola, and many prominent others. This idea has received a broader context in Toyin Falola, "Yoruba Writers and the Construction of Heroes," 157-175, where the long project of cultural revival for the progress of the society is clearly illustrated as the pre-occupation of Yoruba intellectuals since the language was reduced into writing. 